\begin{tabular}{|c|c|c|c|cc|l|}
\hline \multirow{2}{*}{2} & $\mathbf{E ~ D ~ E ~}$ & $\mathbf{3 6} 6$ & \multirow{2}{*}{$\mathbf{B}$} & Dispatch: 1.8 .09 & Journal: EDE & CE: Deepika/Sukanya \\
\cline { 2 - 3 } \cline { 5 - 5 } & Journal Name & Manuscript No. & & Author Received: & No. of pages: 7 & PE: Suseela/Bhuvi \\
\hline
\end{tabular}

EVOLUTION \& DEVELOPMENT $11: 5,602-608$ (2009)

DOI: $10.1111 / \mathrm{j} .1525-142 X .2009 .00366 . x$

\title{
Evolution of germ cell development in tetrapods: comparison of urodeles and amniotes
}

\author{
Rosemary F. Bachvarova,a,* Brian I. Crother,b and Andrew D. Johnsonc

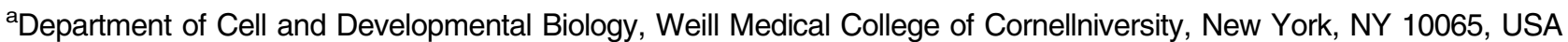 \\ ${ }^{b}$ Department of Biological Sciences, Southeastern Louisiana University, Hammond, LA 70402, USA \\ ${ }^{c}$ Queens Medical Centre, Institute of Genetics, University of Nottingham, Nottingham, NG7 2UH, UK \\ *Author for correspondence (email: bachva@med.cornell.edu)
}

SUMMARY The embryonic development of germ cells in tetrapods is described, focusing on groups with the inductive mode of germ cell specification. In mammals PGCs are induced early in the gastrulation process, they are internalized with future extraembryonic mesoderm in the early posterior primitive streak, and specified soon thereafter. Strong evidence indicates that a similar process occurs in turtles and some other reptiles. In amniotes, the PGCs appear well before formation of the gonad in the posterior trunk, resulting in a period in which they are located outside the embryo before their migration to the gonad. In contrast, in urodeles the PGCs appear relatively late, and throughout development maintain a position close to precursors of the somatic cells of the gonad so that migration is not required. In lampreys early development of germ cells is strikingly similar to that in urodeles, suggesting this is the primitive process. As amniotes evolved large yolky eggs and better access to nutrition, development of the posterior half of the trunk became more dependent on cell proliferation; this was followed or accompanied by a shift of early germ cell development to the equivalent of the early primitive streak. A similar process may have occurred as some basal vertebrates developed large yolky eggs.

\section{INTRODUCTION}

Germ cells play a unique role in maintenance and evolution of the species; they create new combinations of genetic information and form the individuals of the next generation. The processes involved in their specification and early development are of great interest. Two modes of germ cell specification have been defined, the inductive (regulative) mode and the predetermined (germ plasm) mode. In embryos using the inductive mode, cells of the late blastula- early gastrula epiblast or animal cap, that would not normally form germ cells, can be induced to form them by exposure to appropriate tissues or growth factors (Sutasurya and Nieuwkoop 1974;

Tam and Zhou 1996; O'Reilly et al., in preparation). In the predetermined mode, germ cells are specified before gastrulation by germ plasm stored in the egg. The evidence indicates that germ cell specification proceeds by the inductive mode among basal vertebrates and was maintained as ancestral tetrapods evolved to amniotes, whereas the more derived predetermined mode evolved at least three times among vertebrates, in teleosts, in amphibians, and at least once in reptiles (Fig. 1) (Johnson et al. 2001, 2003; Extavour and Akam 2003; Crother et al. 2007; Bachvarova et al. 2009). We will focus on features of germ cell development that evolved during the transition from basal tetrapods to amniotes, but not on the later changes related to the appearance of germ plasm.

We discuss the location of PGCs during early development and the site and timing of PGC specification, finding that these are very similar within the amniotes, specifically turtles and mammals, but very different in urodelean amphibians. One striking feature is that in amniotes but not urodeles PGCs reside for a definite period in the extraembryonic region bordering the embryo before moving through the gut and dorsal mesentery to the gonadal ridges. We speculate that the characteristic features of germ cell development in amniotes are related to the better access to nutrition and the associated more dramatic growth of the trunk. Finally, we suggest that in the large yolky embryos of basal vertebrates development of germ cells may be similar to that in amniotes.

\section{DEVELOPMENT OF PGCS IN TURTLES}

Development of germ cells has been studied in several turtle species using histological techniques (Allen 1906; Dustin 1910; Jordan 1917; Risley 1933; Fujimoto et al. 1979). Recently, expression of the germ cell-specific gene Dazl, encoding an RNA binding protein (see Bachvarova et al. 2009, for references) has been examined in embryos of the freshwater turtle, 


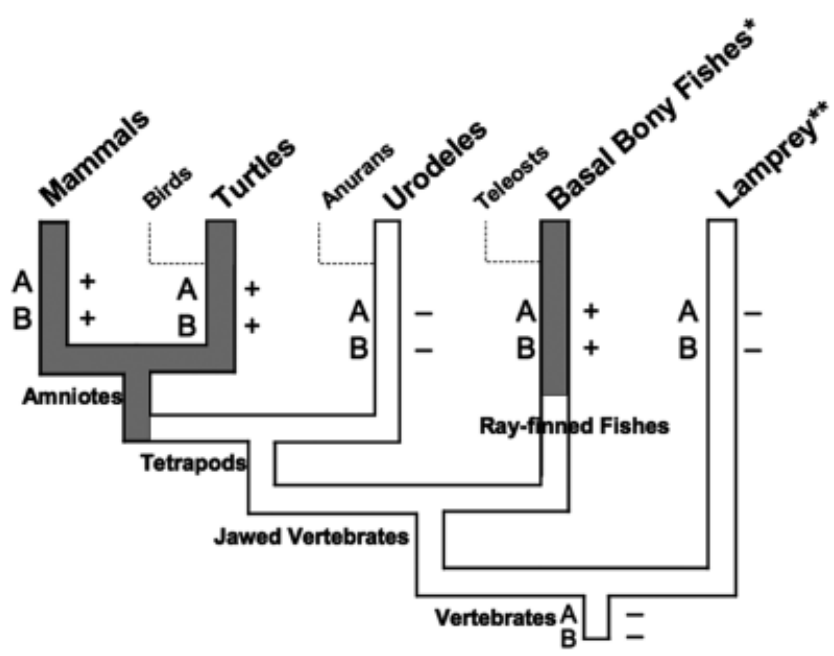

Fig. 1. Hypothesis for changes in the pattern of germ cell development among vertebrates with the inductive mode of germ cell specification. Clades with the predetermined mode arose as indicated by dashed lines but are not included in the evolutionary scenario. The characters are not optimized on the tree but simply mapped to indicate where we infer changes took place. Urodeles are hypothesized to have retained the ancestral condition (unshaded branches) of the induction mode. The derived form of induction (shaded branches) associated with yolky eggs is inferred to have evolved in the branch leading to amniotes, and during the early radiation of ray-finned fishes slightly preceding the appearance of true meroblastic cleavage as indicated by Collazo et al. (1994). (A - ) Germ cell precursors are internalized relatively late in the gastrulation process along with precursors of the somatic cells of the gonad. $(\mathrm{A}+)$ Germ cell precursors are internalized relatively early in the gastrulation process along with extraembryonic mesoderm. They are specified soon thereafter. PGCs are located outside the embryos for a period of time. $(\mathrm{B}-)$ The trunk is generated relatively synchronously with a relatively small contribution from cell proliferation. Nutrition is relatively inefficient. $(\mathrm{B}+)$ The trunk is generated asynchronously with a large contribution from cell proliferation. Access to nutrition is improved. ${ }^{*}$ Basal fish is a paraphyletic group including bow fin, gar, and bichir. The mode of germ cell specification is inferred from the position of germ cells in the embryo. ${ }^{* *}$ The characters indicated for the lamprey are the most likely based on the limited information available.

Trachemys scripta (Bachvarova et al. 2009). Low levels of expression of Dazl were found in scattered cells in the blastoporal plate of the gastrula, the equivalent of the early posterior primitive streak of mammalian embryos. Soon thereafter PGCs expressing Dazl RNA at a higher level were found in or adjacent to the endodermal layer in an oval region below the blastoporal plate. These data suggest that the PGCs of turtle arise, as they do in mammals, by the inductive mode.

During neurulation the PGCs move posteriorly and laterally to form a U-shape around the posterior end of the embryo, lying in the junctional extraembryonic endoderm just outside the embryo. This is the stage at which earlier workers were first able to identify PGCs using histological techniques. "It is evident that the gonocytes of reptiles, which penetrate into the yolk of the germ wall ... and do not come out of it until much later ... seem to shelter in the region of the embryo where morphogenetic modifications are the least intense" (Pasteels 1937, translated by R. F. B.). The PGCs remain just outside the embryo in the posterior region until about the 14-somite stage when they reappear inside the embryo, moving medially through the gut and dorsal mesentery to the gonadal ridges, as described previously.

In addition, expression of both Dazl and Vasa was examined in turtle ovaries (Vasa encodes an ATP-dependent RNA helicase expressed in germ cells of most organisms, see Bachvarova et al. 2009, for references). Neither Dazl RNA nor Vasa RNA or protein were localized in oocytes (Bachvarova et al. 2009). In contrast in another reptile, the chick, Vasa protein is localized in cortical bodies in oocytes and in a few cells of the early embryo (Tsunekawa et al. 2000). In Xenopus Dazl RNA and the protein of the Vasa homolog XVLG1 are localized to germ plasm of the oocyte (Komiya et al. 1994; Houston and King 2000). These data along with the data on early embryos strongly suggest that turtles use the inductive mode of germ cell specification. Older histological data indicate that the position of PGCs is similar in lacertoid lizards to that in the turtle (Hubert 1969, 1985), suggesting that in these as well the PGCs are formed by an inductive mechanism. Phylogenetic analysis indicates that although chick and probably snakes use the predetermined mode, the most likely hypothesis is that the inductive mode is basal among reptiles (Bachvarova et al. 2009).

\section{EARLY DEVELOPMENT OF PGCS IS SIMILAR IN TURTLES AND MAMMALS}

In the mouse, the PGCs can be seen soon after they are specified, as a cluster of cells in the posterior primitive streak at mid-late streak stages (embryonic day 7.5 [E7.5]) (Anderson et al. 2000; Saitou et al. 2002). From there, they move to the base of the allantois and into a region that is apparently a junctional zone between the visceral and definitive endoderm. By the early head fold stage the PGCs form 'a crescent-like distribution: ventral, lateral, and posterior to the primitive streak ...' (Anderson et al. 2000), reminiscent of the crescent found in the turtle. By the three somite stage the PGCs are located in the endoderm of the hind-gut in an arc around the posterior end of the primitive streak.

In the rabbit the early appearance of PGCs has been traced using an antibody specific for germ cells at later stages (Schafer-Haas and Viebahn 2000). The presumptive PGC precursors are seen at the fully extended primitive streak stage scattered in the mesodermal layer of the posterior primitive streak. By the head process stage they are found in a crescentshaped area near the posterior margin of the embryo, in endoderm or in mesoderm closely associated with endoderm. 
In human, bovine, and porcine embryos (Witschi 1948; Wrobel and Suss 1998; Vejlsted et al. 2006) the positions of presumptive PGCs observed from slightly later stages are consistent with those in the turtle, mouse, and rabbit. In all cases they then move through the gut, and the dorsal mesentery to the germinal ridge.

The similarity of the position and movement of PGCs in the turtle and in these mammals is striking. Their precursors are gastrulated through the blastoporal plate or the posterior region of the early primitive streak. Cells moving inward along with these precursors are predominantly extraembryonic mesoderm that is generated in large amounts from the blastoporal plate of the turtle at these stages (Pasteels 1937; Yntema 1968; Gilland and Burke 2004). Similarly the posterior region of the chick and mouse primitive streak produces extraembryonic mesoderm (Streeter 1927; Garcia-Martinez and Schoenwolf 1993; Nagy et al. 2003) and in mice the cells most closely related by lineage to the PGCs are those of the extraembryonic mesoderm of the allantois and yolk sac (Lawson and Hage 1994). The PGCs move as individual cells and soon are found in the extraembryonic endoderm bordering the embryo. After an interval of varying length, they appear more medially in the embryonic gut at early to midsomite stages. This interval is reduced to a minimum in the mouse, presumably because of its very rapid development.

Another major similarity between the turtle and the mammal is that the PGCs are specified at approximately the time they are gastrulated. In the mouse the PGCs are allocated and specified between E6.25 and E7.25 (early-mid primitive streak stages), as shown by the expression of germ cell-specific genes such as stella and nanog and the pluripotency gene Oct4 at mid-streak stages (Saitou et al. 2002; McLaren and Lawson 2005; Hayashi et al. 2007; Chuva de Sousa Lopes and Roelen 2008). In rabbit an apparently germ cell-specific antigen was detected in presumptive PGCs shortly after their ingression (Schafer-Haas and Viebahn 2000). In the pig expression of Oct4 is seen in PGCs at the neural plate stage and expression of kit (a tyrosine kinase receptor whose activation is required for germ cell survival, proliferation, and migration (see Anderson et al. 2001)) appears shortly thereafter (Vejlsted et al. 2006).

Dazl expression in turtles is initiated while the PGCs are still in the blastoporal plate. We assume that PGCs are specified by the time they are located in the lower layer under the blastoporal plate and express $\mathrm{Dazl}$ quite strongly. Apparently in turtle Dazl is an early marker of PGCs, although in mice it is upregulated after the PGCs reach the gonad (Lin and Page 2005). We can only speculate on the significance of turtle PGCs expressing Dazl distinctly earlier than in mouse. We do not yet know how widespread the molecular mechanisms for germ cell specification found in mice will be, and possibly some other mammals will resemble the turtle in this respect.
We conclude that germ cell development in mammals and in reptiles with the basal pattern of germ cell location found in turtles is similar in that germ cell precursors are internalized along with posterior extraembryonic mesoderm early in the gastrulation process, and they are specified soon thereafter. They are located outside the embryo for a period, before moving through the gut and dorsal mesentery to the gonad.

\section{DEVELOPMENT OF PGCS IN URODELES}

In urodeles (salamanders and newts) gastrulation occurs at the crescent-shaped and later circular blastopore (for a comparison of urodele and amniote gastrulation, see Arendt and Nübler-Jung 1999; Shook and Keller 2008). The posterior trunk mesoderm forms from material involuting around the lateral and ventral lips of the blastopore.

Fate mapping and transplant studies have shown that the precursors of the PGCs are located on the surface near the ventral lip of the blastopore at the late gastrula stage, they involute around the ventral lip of the blastopore along with the lateral plate of the posterior trunk, and in early tail bud embryos arrive in the dorsal lateral plate adjacent to intermediate mesoderm (Fig. 2) (Humphrey 1925, 1927, 1929; Nieuwkoop 1947; Smith 1964; Maufroid and Capuron 1972). As the coelom forms, the PGCs, along with several other cell types, including the coelomic epithelial cells that give rise to the early gonadal epithelium, all move medially (Humphrey 1925; Nieuwkoop 1947; Johnson et al. 2001). The PGCs are found on the somatic side of the coelom, rather than on the splanchnic side, as in turtles and mammals. The gonadal ridges containing both germ and somatic cells then form on either side of the midline (Fig. 2).

\section{CHANGES IN GERM CELL AND TRUNK DEVELOPMENT AS AMNIOTES EVOLVED FROM BASAL TETRAPODS}

Two sets of changes (A, B) are described below and are indicated on a phylogenetic tree of vertebrates in Fig. 1. In the discussion below we use the urodele to represent basal tetrapods.

(A) Changes in germ cell development

(i) Changes in timing and site of internalization of germ cells: in amniotes the prospective germ cells are internalized relatively early along with prospective extraembryonic mesoderm long before the gonad is formed in the posterior trunk, while in urodeles the germ cells are internalized along with posterior lateral mesoderm and prospective gonad. To set the stage, we note that the gastrulation process, defined for the purpose of this discussion as the formation of the internal mesoderm of the head and trunk, is markedly asynchronous in amniotes. In 


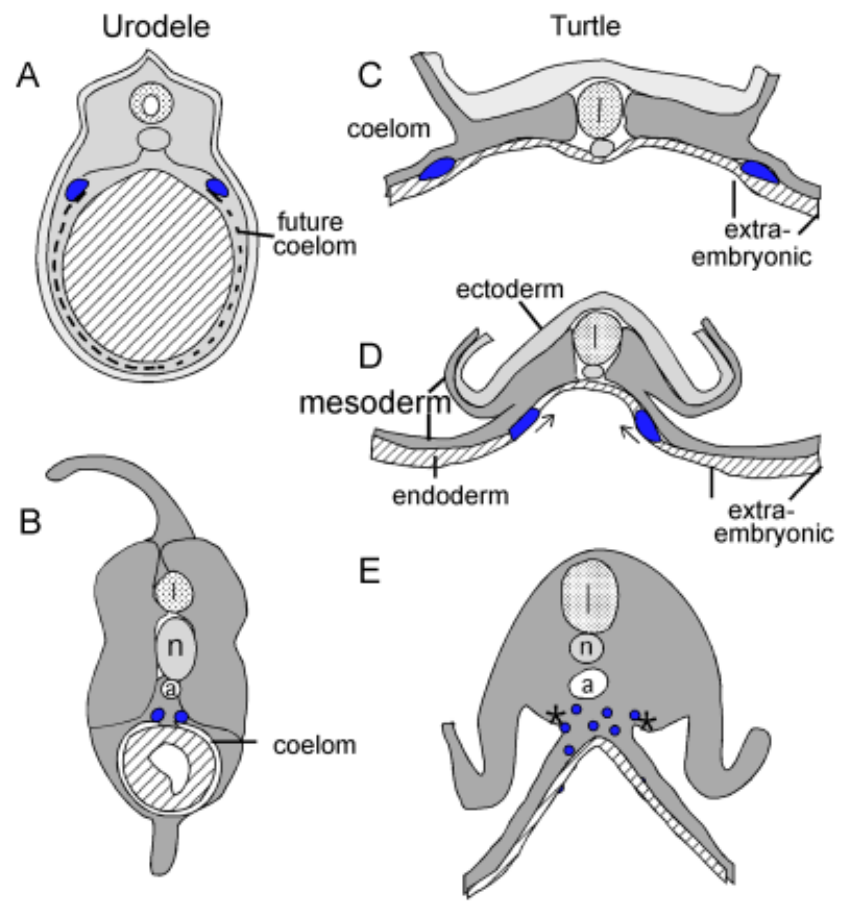

Fig. 2. Diagrams of cross sections of the posterior trunk of urodele (axolotl) and turtle embryos, showing the position of germ cells (blue). In axolotl the germ cells and somatic cells of the gonad are found in the dorsal lateral plate in late tail bud embryos (A), are located on the somatic side of the coelom as it forms, and move together to their definitive position near the midline (B). In turtles and other amniotes, the germ cells arrive during the neurula stage at a position in the junctional endoderm just outside the embryo, as shown for an early somite embryo $(\mathrm{C})$. They remain outside the embryo as the posterior trunk forms, and then are found more medially within the embryonic endoderm (D), and finally move in the root of the dorsal mesentery around the coelomic angle (E) to their final position in the gonadal ridge $\left({ }^{*}\right)$. For simplicity the ectoderm is not shown in (B and $\mathrm{E})$.

these embryos, there is an anterior to posterior gradient such that development of the cranial region is well underway, with branchial arches forming, before the prospective posterior trunk mesoderm has been internalized. In contrast in urodeles the gastrulation process takes place over a short period at gastrula and neurula stages and is almost completed before the first head somites form.

In amniotes (turtles and mammals) the PGCs are formed along with extraembryonic mesoderm early in the gastrulation process as described above, and are placed outside the embryo where they remain for a period before returning on their route to the gonad (see Fig. 2). This period extends from about the neurula to the mid-somite stage. In contrast the somatic portion of the gonad forms relatively late as the posterior trunk develops. In the mouse the gonad forms at about E10 and the mesoderm of the lower thoracic and lumbar regions containing the presumptive gonad is internalized around E9 (embryos of 12-16 somites). In the turtle it can be estimated that the gonad precursors are internalized during the 9-18 somite stages, long after germ cells have appeared. During the period between appearance of the germ cells and formation of the gonad, the PGCs are placed just outside the boundary of the embryo, and much later become associated with somatic cells of the gonad.

In contrast in the urodele, the germ cell precursors are located from at least mid-gastrula stage among or near the precursors of the gonad, and are internalized late in the gastrulation process along with lateral mesoderm of the posterior trunk and close to intermediate mesoderm that will form the gonad. As the coelom forms they remain on the somatic side and migrate medially with the coelomic epithelium to the final position of the gonad (see Fig. 2). Thus they do not require a long migration to their final location, there is no equivalent of the period in which PGCs are placed outside the embryo, and little need for movement of the PGCs relative to the gonad tissue.

We note in passing that in amniotes PGCs are often associated with endoderm rather than mesoderm after inward movement and during the period they are placed outside the embryo. Their association with the junctional endoderm may prevent them from being carried around the embryo along with extraembryonic mesoderm. This phenomenon may also be related to the finding that parts of the gut along the whole anterior-posterior axis are established relatively early in chick and mouse (Lawson and Schoenwolf 2003; Kimura et al. 2006; Tam et al. 2007). In contrast mesoderm is formed sequentially from anterior to posterior end. Thus soon after ingression, the PGCs may become associated with the future mid-hindgut region. They may remain at this position along the anterior-posterior axis as the gut is formed and lengthens, and as the PGCs return to the embryo. Because the PGCs are located for a period just outside the embryo, this hypothesis would require that the junctional region have the same anterior-posterior specification as the embryonic gut.

(ii) In amniotes specification of germ cells occurs soon after internalization whereas in urodeles the evidence suggests that this occurs somewhat later. The evidence on this point for amniotes was discussed above. In urodeles germ cells are internalized late in the gastrulation process, and specification may occur even later. In the Mexican salamander axolotl expression of Dazl is first detected in PGCs in the dorsal lateral plate at a late tail bud stage (about 22 somites) and Vasa somewhat later at an early larva/gill formation stage (Bachvarova et al. 2004). PGCs may be detected histologically at mid-tail bud stages (Humphrey 1925, 1927, 1929). With the limited information available we assume that specification occurs around the time of onset of Dazl and Vasa expression. So far attempts to locate PGCs or their precursors at earlier stages have failed. Among the germ cell markers expressed in mammalian PGCs between gastrulation and arrival in the gonad are $c$-kit and Oct4. Although Axoct4 is expressed in the 
animal cap and in early posterior mesoderm, no expression is found from neurula stage through early larval stages. Axkit was not expressed in cells that were plausible precursors of PGCs at these stages (Bachvarova et al. 2004). Germ cells are induced in axolotl animal caps in parallel with mesodermal tissues by ventral vegetal zones (Sutasurya and Nieuwkoop 1974) and by mesoderm inducing factors (O'Reilly et al., in preparation), but the sequence of events during the several days between the onset of induction and specific gene expression is unknown. In urodeles unidentified molecular processes may maintain the ability of the germ line cells to give off somatic derivatives over a relatively long time.

(B) Changes in trunk development and nutrition

(i) The trunk is generated more asynchronously and cell proliferation contributes more to growth of the trunk in amniotes than in urodeles. The contribution of cell proliferation to the generation of trunk tissues changes as more posterior trunk regions are formed. In amniotes the cranial region and anterior trunk develop as cells move toward the primitive streak or blastopore and internalize to form mesoderm, and subsequently more posterior trunk mesoderm is generated from a small structure, the late primitive streak or trunk/ tail bud. This latter process supports growth primarily by generation of cells within the structure from progenitor cells or stem cells, rather than by incorporation of cells from the outside (Cambray and Wilson 2002; Stern et al. 2006). In turtles the trunk posterior to about five somites is generated from the remnants of the blastopore, a trunk/tail bud, and the remnants of the blastoporal plate (Gilland and Burke 2004).

In amphibians trunk mesoderm is essentially in place by the end of the neurula stage, suggesting relatively little contribution of cell proliferation during this short gastrulation process. Limited additional evidence also suggests that the increasing role of cell proliferation along the axis is less dramatic than in amniotes (see Stern et al. 2006). It appears that prospective posterior somites can be mapped on the surface of the embryo from gastrula to neural plate stages (Pasteels 1942; Spofford 1945; Holtfreter and Hamburger 1955; Lane and Sheets 2006), indicating that the set of posterior somites are not generated from a small population of stem cells. In Xenopus cell labeling experiments indicate a change at the neurula stage from involution through the late blastopore to generation of the most posterior trunk and tail region from within the tail bud (Gont et al. 1993). However, Delarue et al. (1995) did not find stem cells for trunk mesoderm on the surface of the early urodele gastrula.

Taken together the evidence indicates that in amniotes a significant proportion of the posterior trunk mesoderm is generated from stem cells that proliferate within a small region of the embryo. In urodeles the evidence suggests that most of the spatial allocation of trunk structures occurs before internalization, consistent with the relatively synchronous formation of the head and trunk. (ii) Amniote embryos have better access to nutrition and oxygen than urodele embryos. Amniotes develop extraembryonic membranes, including the yolk sac, which from an early stage surrounds the yolk and contributes to nutrition and oxygen supply by absorption of yolk and generation of primitive red blood cells. (Mammals develop a large yolk sac although they lack yolk.) Blood circulation starts between about the 5 somite and 15 somite stages before or during posterior trunk formation. We propose that the dramatic cell proliferation required for growth of the amniote trunk is related to the improved access to nutrition and oxygen.

In contrast urodeles have a moderate amount of yolk, most of which is not absorbed until after the hatching larval stage. Blood circulation starts after the body axis has fully formed. They lack extraembryonic membranes, and lack an equivalent of the early posterior primitive streak/blastoporal plate of amniotes that generates extraembryonic mesoderm, although the mesoderm of the ventral blood island that produces primitive blood may be a forerunner. This mesoderm is generated from the early ventral lip of the blastopore in axolotl (Nieuwkoop 1947; A. D. Johnson, et al., in preparation).

\section{CONCLUSION AND HYPOTHESES FOR TETRAPODS}

Although a discussion of the interrelations of nutrition, growth, and evolutionary changes in embryonic development are beyond the scope of this review, we emphasize here that improved nutrition may have permitted more rapid cell proliferation to generate the posterior trunk, followed or accompanied by a shift of early germ cell development from the region of the posterior trunk in urodeles to an earlier developmental time period and a new site, the early posterior primitive streak/blastoporal plate. This results in the characteristic feature of amniote germ cell development, their location outside the embryo during trunk formation.

We propose that it may have been deleterious for the PGC precursors to remain among the rapidly proliferating tissues of the forming trunk in the late primitive streak of amniotes. Rapid cell division is likely to increase the mutation rate, which may be particularly disadvantageous when it occurs in germ cell precursors (see Extavour 2007). This may have provided the selective force for the change in site and timing of germ cell formation.

\section{EVOLUTION OF GERM CELL DEVELOPMENT IN VERTEBRATES}

Among basal vertebrates, sharks and probably skates (Beard 1902a, b; Woods 1902) and a few basal ray-finned fishes for which there is sufficient information (bowfin and gar, Allen 
1911; bichir, De Smet 1970) show a strong similarity to the amniotes in the early location and path of movement of the PGCs to the gonad. In these fishes and elasmobranchs the germ cells are first detected in or associated with the extraembryonic endoderm near the border of the embryo; they then move through the embryonic gut and dorsal mesentery to the gonadal ridge. We hypothesize that in these forms the PGCs are generated by an inductive mechanism, and the location and timing of germ cell development are similar to those in amniotes. In these forms the embryos cleave meroblastically, or almost meroblastically as in the bowfin (Ballard 1986), form a large external yolk sac, and the trunk is generated more asynchronously than in urodeles. The independent evolution of increased yolk in elasmobranches, basal ray-finned fishes, and amniotes (Collazo et al. 1994) may have resulted in similarities in gastrulation (Arendt and NüblerJung 1999), and possibly in germ cell development. The sturgeon may be an intermediate form - its embryo undergoes holoblastic cleavage, gastrulates like the urodele, and has a moderate sized yolk sac (Ballard and Ginsburg 1980; Bolker 1993). Little is known about its germ cells (see Maschkowzeff 1935), but its oocytes do not localize germ plasm RNAs (Zelazowska et al. 2007), consistent with an inductive mechanism. The relationship between better nutrition and growth of the posterior trunk via cell proliferation requires further analysis in these embryos.

In contrast, in the lamprey, an agnathan, the germ cells first appear at early somite stages in a position very similar to that in axolotl embryos, in newly invaginated mesoderm and then in the dorsal lateral plate, later moving medially apparently with somatic cells of the gonad as in urodeles, on the somatic side of the coelom to the site of gonad formation (Wheeler 1899; Okkelberg 1921). Moreover the blastula fate map and gastrulation process resemble those in urodeles (see Nieuwkoop and Sutasurya 1979). Little is known about PGCs in the lungfish, the closest living relative of the tetrapod ancestor, but its development through gastrulation and trunk formation quite closely resembles that of the urodeles (Kemp 1982). Our recent evidence suggests that its oocytes do not contain germ plasm (Johnson et al. 2003).

Looking lower in the evolutionary tree, in the cephalochordate amphioxus the germ cells appear at the ventral edge of the somites as do the first gonadal cells, reminiscent of the process in urodeles (see Nieuwkoop and Sutasurya 1979).

This brief survey suggests that the amniote pattern (early generation of PGCs that move to posterior junctional endoderm, and path to the gonad via the gut and dorsal mesentery) is highly correlated with embryos that have a high yolk content and meroblastic cleavage (or descended from such embryos as are mammals). The evidences strongly supports the hypothesis that holoblastic cleavage and relatively low yolk content are basal among chordates and large yolky eggs evolved in several lineages (Collazo et al.
1994). Consistent with this hypothesis, we propose that the urodele-lamprey pattern of germ cell development is basal among vertebrates (Fig. 1). Extraembryonic structures of the yolk sac were developed for early blood cell formation, and for absorption of yolk. Early access to nutrition and oxygen clearly provide a major advantage to these embryos. Thus it appears that as a consequence of gaining these advantages and associated changes in the primitive streak, early germ cell development was altered significantly. Germ cell precursors came to be specified early, gastrulated with extraembryonic mesoderm and placed just outside the embryo until the posterior trunk was formed.

\section{REFERENCES}

Allen, B. M. 1906. The origin of the sex-cells in Chrysemys. Anat. Anz. 2: 217-236.

Allen, B. M. 1911. The origin of the sex-cells of Amia and Lepidosteus. J. Morphol. 22: 3-36.

Anderson, R., Copeland, T. K., Scholer, H., Heasman, J., and Wylie, C. 2000. The onset of germ cell migration in the mouse embryo. Mech. Dev. 91: $61-68$.

Anderson, R., Heasman, J., and Wylie, C. 2001. Early events in the mammalian germ line. Int. J. Cytol. 215-230.

Arendt, D., and Nübler-Jung, K. 1999. Rearranging gastrulation in the name of yolk: evolution of gastrulation in yolk-rich amniote eggs. Mech. Dev. 81: 2-22.

Bachvarova, R. F., et al. 2004. Gene expression in the axolotl germ line: Axdazl, Axvh, Axoct-4, and Axkit. Dev. Dyn. 231: 871-880.

Bachvarova, R. F., et al. 2009. Expression of Dazl and Vasa in turtle embryos and ovaries: evidence for inductive specification of germ cells. Evol. Devo. 11: 524-533.

Ballard, W. W., and Ginsburg, A. S. 1980. Morphogenetic movements in acipenserid embryos. J. Exp. Zool. 213: 391-399.

Beard, J. 1902a. The germ cells. Part I. Raja batis. Zool. Jahrb. Abt. Anat. Ontog. Tiere 16: 615-702.

Beard, J. 1902b. The germ cells of Pristiuris. Anat. Anz. 21: 50-61.

Bolker, J. A. 1993. Gastrulation and mesoderm morphogenesis in the white sturgeon. J. Exp. Zool. 266: 116-131.

Cambray, N., and Wilson, V. 2002. Axial progenitors with extensive potency are localized to the mouse chordoneural hinge. Development 129: 4855-4866.

Chuva de Sousa Lopes, S. M., and Roelen, B. A. J. 2008. Primordial germ cell specification: the importance of being 'blimped'. Histol. Histopathol. 23: $1553-1561$.

Collazo, A., Bolker, J. A., and Keller, R. 1994. A phylogenetic perspective on teleost gastrulation. Am. Nat. 144: 133-152.

Crother, B. I., White, M. E., and Johnson, A. D. 2007. Inferring developmental constraint and constraint release: primordial germ cell determination mechanisms as examples. J. Theor. Biol. 248: 322-330.

Delarue, M., Saez, F. J., Johnson, K. E., and Boucaut, J.-C. 1995. Restriction of cell fate of superficial cells in the marginal zone of the amphibian embryo Pleurodeles waltl. J. Exp. Zool. 273: 303-316.

De Smet, W. M. A. 1970. The germ cells of Polypterus (Brachiopterygii, Pisces). Acta Morphol. Neerl.-Scand. 8: 133-141.

Dustin, A. P. 1910. L'origine et l'evolution des gonocytes chez les reptiles (Chrysemis marginata). Arch. Biol. 25: 495-534.

Extavour, C. G., and Akam, M. 2003. Mechanisms of germ cell specification across the metazoans: epigenesis and preformation. Development 130: 5869-5884.

Extavour, C. G. M. 2007. Evolution of the bilaterian germ line: lineage origin and modulation of specification mechanisms. Integr. Comp. Biol. 47: $770-785$.

Fujimoto, T., Ukeshima, A., Miyayama, Y., Horio, F., and Ninomiya, E. 1979. Observations of primordial germ cells in the turtle embryo (Caretta 
caretta): light and electron microscopic studies. Dev. Growth Differ. 21: $3-10$.

Garcia-Martinez, V., and Schoenwolf, G. C. 1993. Primitive streak origin of the cardiovascular system in avian embryos. Dev. Biol. 159: 706-719.

Gilland, E. H., and Burke, A. C. 2004. Gastrulation in reptiles. In C. D. Stern (ed.). Gastrulation: From Cells to Embryo. Cold Spring Harbor Laboratory Press, New York, pp. 205-217.

Gont, L. K., Steinbeisser, H., Blumberg, B., and De Robertis, E. M. 1993. Tail formation as a continuation of gastrulation: the multiple cell populations of the Xenopus tailbud derive from the late blastoporal lip. Development 119: 991-1004.

Hayashi, K., de Sousa Lopes, S. C., and Surani, M. A. 2007. Germ cell specification in mice. Science 316: 394-397.

Holtfreter, J., and Hamburger, V. 1955. Amphibians. In B. H. Willier, P. A Weiss, and V. Hamburger (eds.). Embryogenesls: Progressive Differentiation. Analysis of Development. pp. 230-296.

Houston, D. W., and King, M. L. 2000. A critical role for Xdazl, a germ plasm-localized RNA, in the differentiation of primordial germ cells in Xenopus. Development 127: 447-456.

Hubert, J. 1969. Localisation precoce et mode de migration des gonocytes primordiaux chez quelques reptiles. Ann. Embryol. Morphogen. 2: 479494.

Hubert, J. 1985. Origin and development of oocytes. In C. Gans, F. Billet, and P. F. A. Maderson (eds.). Biology of the Reptilia, Vol. 14, Development A. John Wiley and Sons, New York, pp. 42-74.

Humphrey, R. R. 1925. The primordial germ cells of Hemidactylium and other amphibia. J. Morph. Physiol. 41: 1-43.

Humphrey, R. R. 1927. Extirpation of the primordial germ cells of Amblystoma: its effect upon the development of the gonad. J. Exp. Zool. 49: 363-399.

Humphrey, R. R. 1929. The early position of the primordial germ cells in urodeles: evidence from experimental studies. Anat. Rec. 42: 301-314.

Johnson, A. D., Bachvarova, R. F., Drum, M., and Masi, T. 2001. Expression of axolotl $D A Z L$ RNA, a marker of germ plasm: widespread maternal RNA and onset of expression in germ cells approaching the gonad. Dev. Biol. 234: 402-415.

Johnson, A. D., Drum, M., Bachvarova, R. F., Masi, T., White, M. E., and Crother, B. I. 2003. Evolution of predetermined germ cells in vertebrate embryos: implications for macroevolution. Evol. Dev. 5: 414431.

Jordan, H. E. 1917. The history of the primordial germ cells in the loggerhead turtle embryo. Proc. Natl. Acad. Sci. USA. 3: 271-275.

Kemp, A. 1982. The embryological development of the Queensland lungfish, Neoceratodus forsteri (Krefft). Mem. Queensl. Mus. 20: 553-598.

Kimura, W., Yasugi, S., Stern, C. D., and Fukada, K. 2006. Fate and plasticity of the endoderm in the early chick embryo. Dev. Biol. 289: 283295.

Komiya, T., Itoh, K., Ikenishi, K., and Furusawa, M. 1994. Isolation and characterization of a novel gene of the DEAD box protein family which is specifically expressed in germ cells of Xenopus laevis. Dev. Biol. 162: 354-363.

Lane, M. C., and Sheets, M. D. 2006. Heading in a new direction: implications of the revised fate map for understanding Xenopus laevis development. Dev. Biol. 296: 12-28.

Lawson, A., and Schoenwolf, G. C. 2003. Epiblast and primitive-streak origins of the endoderm in the gastrulating chick embryo. Development 130: 3491-3501.

Lawson, K. A., and Hage, W. J. 1994. Clonal analysis of the origin of primordial germ cells in the mouse. Ciba Found. Symp. 182: 68-91.

Lin, Y., and Page, D. C. 2005. Dazl deficiency leads to embryonic arrest of germ cell development in XY C57BL/6 mice. Dev. Biol. 288: 309-316.

Maschkowzeff, A. 1935. Zur phylogenie des geschlechtsdrusen und der geschlechtsausfurgange bei den vertebrata auf grund von forschungen betreffend die entwicklung des mesonephros und der geschlechtsorgane bei den Acipenseridae, Salmoniden und Amphibien. I. Zool. Jahrb. Abt. Anat. Ontog. Tiere 59: 1-68, 201-276.

Maufroid, J. P., and Capuron, A. P. 1972. Migration des cellules germinales primordiales chez l'amphibien urodele Pleurodeles waltlii Michah. Wilhelm Roux' Archiv. 170: 234-243.
McLaren, A., and Lawson, K. A. 2005. How is the mouse germ-cell lineage established? Differentiation 73: 435-437.

Nagy, A., Gertsenstein, M., Vintersten, K., and Behringer, R. 2003. Manipulating the Mouse Embryo. Cold Spring Harbor Press, New York.

Nieuwkoop, P. D. 1947. Experimental investigations on the origin and determination of the germ cells and on the development of the lateral plates and germ ridges in the urodeles. Arch. Neer. Zool. 8: 1-205.

Nieuwkoop, P. D., and Sutasurya, L. A. 1979. Primordial Germ Cells in the Chordates. Cambridge University Press, Cambridge.

Okkelberg, P. 1921. The early history of the germ cells in the brook lamprey, Entosphenus wilderi (Gage). J. Morphol. 35: 1-151.

Pasteels, J. 1937. Etudes sur la gastrulation des vertebres meroblastiques. II. Reptiles. Arch. Biol. 48: 105-184.

Pasteels, J. 1942. New observations concerning the maps of presumptive areas of the young amphibian gastrula (Ambystoma and Discoglossus). J. Exp. Zool. 89: 255-281.

Risley, P. L. 1933. Contributions on the development of the reproductive system in Sternotherus odoratus (Latreille). Z. Zellforsch. Mikrosk. Anat. 18: 459-492.

Saitou, M., Barton, S.C, and Surani, M. A. 2002. A molecular programme for the specification of germ cell fate in mice. Nature 418: 293-300.

Schafer-Haas, A., and Viebahn, C. 2000. The germ cell epitope PG-2 is expressed in primordial germ cells and in hypoblast cells of the gastrulating rabbit embryo. Anat. Embryol. 202: 13-23.

Shook, D. R., and Keller, R. 2008. Epithelial type, ingression, blastopore architecture and the evolution of chordate mesoderm morphogenesis. J. Exp. Zool. (Mol. Dev. Evol.) 310B: 85-110.

Smith, L. D. 1964. A test of the capacity of presumptive somatic cells to transform into primordial germ cells in the Mexican axolotl. J. Exp. Zool. 156: 229-242.

Spofford, W. R. 1945. Observations on the posterior part of the neural plate in Amblystoma. J. Exp. Zool. 99: 35-52.

Stern, C. D., et al. 2006. Head-tail patterning of the vertebrate embryo: one, two, or any unresolved problems? Int. J. Dev. Biol. 50: 3-15.

Streeter, G. L. 1927. Development of the mesoblast and notochord in pig embryos. Contrib. Embryol., Carnegie. Instn. 19: 73-92.

Sutasurya, L. A., and Nieuwkoop, P. D. 1974. The induction of the primordial germ cells in the urodeles. Wilhelm Roux' Arch. 175: 199-220.

Tam, P. P., and Zhou, S. X. 1996. The allocation of epiblast cells to ectodermal and germ-line lineages is influenced by the position of the cells in the gastrulating mouse embryo. Dev. Biol. 178: 124-132.

Tam, P. P. L., et al. 2007. Sequential allocation and global pattern of movement of the definitive endoderm in the mouse embryo during gastrulation. Development 134: 251-260.

Tsunekawa, N., Naito, M., Sakai, Y., Nishida, T., and Noce, T. 2000. Isolation of chicken vasa homolog gene and tracing the origin of primordial germ cells. Development 127: 2741-2750.

Vejlsted, M., Offenberg, H., Thorup, F., and Maddox-Hyttel, P. 2006. Confinement and clearance of OCT4 in the porcine embryo at stereomicroscopically defined stages around gastrulation. Mol. Reprod. Dev. 73: 709-718.

Wheeler, W. M. 1899. The development of the urinogenital organs of the lamprey. Zool. Jahr., Anat. Ontog. Tiere 13: 1-88.

Witschi, E. 1948. Migration of the germ cells of human embryos from the yolk sac to the primitive gonadal folds. Contr. Embryol. Carnegie. Instn. 32: $67-80$, plus plates.

Woods, F. A. 1902. Origin and migration of the germ-cells in Acanthias. Am. J. Anat. 1: 307-320.

Wrobel, K.-H., and Suss, F. 1998. Identification and temporospatial distribution of bovine primordial germ cells prior to gonadal sexual differentiation. Anat. Embryol. 197: 451-467.

Yntema, C. L. 1968. A series of stages in the embryonic development of Chelydra serpentina. J. Morphol. 125: 219-252.

Zelazowska, M., Kilarski, W., Bilinski, S. M., Podder, D. D., and Kloc, M. 2007. Balbiani cytoplasm in oocytes of a primitive fish, the sturgeon Acipenser gueldenstaedtii, and its potential homology to the Balbiani body (mitochondrial cloud) of Xenopus laevis oocytes. Cell Tissue Res. 329: 137-145. 


\section{Author Query Form}

\section{Journal EDE \\ Article $\quad 366$}

Dear Author,

During the copy-editing of your paper, the following queries arose. Please respond to these by marking up your proofs with the necessary changes/additions. Please write your answers clearly on the query sheet if there is insufficient space on the page proofs. If returning the proof by fax do not write too close to the paper's edge. Please remember that illegible mark-ups may delay publication.

\begin{tabular}{|c|l|c|}
\hline Query No. & \multicolumn{1}{|c|}{ Description } & Author Response \\
\hline Q1 & AUTHOR: Please provide author initials for O\&apos;Reilly. & \\
\hline Q2 & AUTHOR: Ballard, 1986 has not been included in the Reference List, please supply full publication details. & \\
\hline Q3 & AUTHOR: Please provide volume for reference Anderson et al., 2001 & \\
\hline Q4 & AUTHOR: Please provide publisher and city location of publisher for reference Holtfreter and Hamburger, 1955. & \\
\hline & & \\
\hline & & \\
\hline
\end{tabular}

